\title{
Reduction of soil contamination by cypermethrin residues using phytoremediation with Plantago major and some surfactants
}

\author{
Ahmed A. A. Aioub ${ }^{1,2,3}$, Yankai Li ${ }^{1,2}$, Xingtao Qie ${ }^{1,2}$, Xianxia Zhang ${ }^{1,2}$ and Zhaonong $\mathrm{Hu}^{1,2^{*}}$ (D)
}

\begin{abstract}
Background: Surfactant-enhanced phytoremediation is an eco-friendly treatment for reducing soil contamination. Cypermethrin (CYP) is one of the most widely used pyrethroid insecticides against different pests, and its use causes soil contamination. The aim of this study was to investigate the removal of CYP from contaminated soil by Plantago major (PM) and some surfactants. For the first time, we documented the uptake and translocation of CYP from the soil and used some strategies to improve the effectiveness of this technology, which involved the use of various surfactants to solubilize the contaminant. In a pot experiment, four surfactants [liquid silicon dioxide $\left(\mathrm{SiO}_{2}, 750 \mathrm{mg} \mathrm{L}^{-1}\right)$, 2-hydroxypropyl-beta-cyclodextrin (HPßCD, 1\%), humic acid (HA, $10 \mathrm{mg} \mathrm{L}^{-1}$ ) and Tween 80 (Tw80, 9.2 $\left.\mathrm{mg} \mathrm{L}^{-1}\right)$ ] were used to facilitate the phytoremediation of CYP $\left(10 \mu \mathrm{g} \mathrm{g}^{-1}\right)$-contaminated soil by PM.

Results: Our data showed that amending the soil with $\mathrm{PM}_{\text {plus }} \mathrm{SiO}_{2}$ significantly reduced the amount of CYP in the soil and highly increased the concentrations of CYP in the plant roots and leaves. The longest half-life value $\left(t_{1 / 2}\right)$

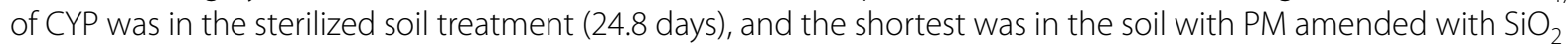
(6.41 days). The half-life value ( $\left.t_{1 / 2}\right)$ of CYP in soil with PM alone was 10.0 days. Through in vitro experiments, a batch equilibrium technique showed that hydroxypropyl- $B$-cyclodextrin (HPßCD) is the best surfactant to most efficiently eliminate CYP from the soil. However, in the greenhouse experiment, the addition of $\mathrm{SiO}_{2}$ to soil cultivated with PM was more effective than the use of other solubility-enhancing surfactants in the removal of significant amounts of CYP $(p>0.05)$ from the contaminated soil.
\end{abstract}

Conclusions: The integration of $\mathrm{SiO}_{2}+\mathrm{PM}$ is the best treatment and is recommended for minimizing plant contaminant contents in CYP-contaminated soil.

Keywords: Removal, Soil polluted, Plant uptake, Solubility enhancing agents, Insecticide

\section{Background}

Millions of megagrams of pesticides annually have been applied in agriculture to increase production by reducing the harmful effects caused by organisms such as viruses, fungi, insects, bacteria, and weeds that grow among economic crops [1]. Pesticide consumption around the world

\footnotetext{
*Correspondence: huzhaonong@nwsuaf.edu.cn

1 Institute of Pesticide Science, College of Plant Protection, Northwest A\&F University, Yangling 712100, Shaanxi, China

Full list of author information is available at the end of the article
}

increased from $2285 \mathrm{Gg}$ active ingredients year ${ }^{-1}$ in 1990 to $4088 \mathrm{Gg}$ active ingredients year ${ }^{-1}$ in 2016 [2]. One of the most substantial problems with pesticide application is their persistence in the environment; moreover, chemicals applied to agricultural fields may be transported to and pollute other ecological systems [3]. Subsequently, these toxic compounds have been involved in various disorders and diseases, including tremors, fasciculation, convulsion, coma, pulmonary oedema, respiratory failure and cardiac conduction disturbances [4]. Cypermethrin (CYP) is a synthetic pyrethroid insecticide that is used 
worldwide on crops to control a wide range of insects [5, 6]. CYP has carcinogenic and cocarcinogenic potentials and can produce compounds with endocrine activity, such as 3-phenoxybenzoic acid [7] and oestrogenic activities [8]. The hydrophobic properties of pyrethroids generally cause strong sorption of these compounds into soil particles, which may cause the formation of bound residues [9] and render CYP rather immobile in soil due to its high $\log K_{\mathrm{OC}}$ value (soil adsorption coefficient) [10]. Moreover, the environmental fate of CYP under ambient conditions is controlled by abiotic factors, such as temperature, redox potential, $\mathrm{pH}$, humidity, organic matter content and light intensity, and, most importantly, also likely by microbial catabolism $[11,12]$. CYP was reported to have a very high octanol-water partition coefficient $\left(K_{\mathrm{ow}}=3.98 \times 10^{6}\right)$. Consequently, it strictly binds to organic matter [13]. As a result, this pesticide causes high contamination of the soil and thus affects non-target organisms. To the best of our knowledge, no reports have been published about the remediation of CYP-contaminated soil.

There are many methods (excavation, physical removal and in situ fixation) to remove toxic hazards from soil. Despite their high efficiency, the majority of these techniques are very expensive [14]. Moreover, in addition to these processes, growing plants can help contain or reduce hazard toxic pollution. This is often called phytoremediation [14]. Phytoremediation, one of the most environmentally sound and cost-effective methods for the decontamination and detoxification of pesticidecontaminated environments, is an emerging technology that utilizes green plants and their associated rhizosphere microorganisms to clean polluted environmental media, especially to remove contaminants from soil and water, such as persistent organic pollutants [15], chemical-industry's organic pollutants [16] and pesticides [17]. Phytoremediation not only uses plants by several methods to contain or clean up toxic hazards but also has the benefit of being a relatively low-cost, natural solution to an environmental problem [18]. The uptake, accumulation, translocation and metabolism of micro-contaminants by plants have been suggested as being important mechanisms for phytoremediation technology [19]. Phytoremediation takes benefit of the selective and unique absorption abilities of the root systems of the plant together with the translocation and bioaccumulation of the whole plant body [20]. Interestingly, more research is highly in need for better understanding the interactions among plants, soil, microbes and the contaminants in order to broaden the successful application of phytoremediation [21]. Therefore, we used this rapid and inexpensive solution to reduce CYP residue in the soil.
There are some factors that affect the efficiency of the phytoremediation of pesticides, such as the $K_{\mathrm{OC}}$ and $K_{\text {ow }}$ values, while pesticides absorbed by soil particles that often remain in the root zone, where they may be more available for plant uptake and chemical or microbial degradation. However, pesticides that are strongly sorbed to the soil are usually less available for microbial degradation and plant uptake [22]. Turgut [23] found that the uptake and translocation of organic compounds were dependent on hydrophobicity (lipophilicity), solubility, polarity, molecular weight, plant species and environmental factors. Pesticides that sorb weakly to soil particles are more likely to move through the soil profile with infiltrating water [22]. The uptake of pesticides by plants is governed by both pesticide and plant characteristics [24]. Moreover, Bouldin et al. [25] recorded that lipophilicity was the most essential characteristic of a chemical to determine its movement within the plant and was associated with the $K_{\text {ow }}$ value. Notably, $\log K_{\text {ow }}$ of pesticides should typically range from 3.0 to 0.5 for optimum uptake. However, pesticides with small $\log K_{\text {ow }}$ are too hydrophilic to pass through cell membrane, whereas the higher $\log K_{\mathrm{ow}}$ are hydrophobic and may be strongly adsorbed onto roots [25]. Moreover, the pesticides with high $K_{\mathrm{OC}}$ value, the soil strongly is sorbed the pesticide, and the plant difficultly uptake and transport it [22].

The common broadleaved plantain plant (Plantago major; $\mathrm{PM}$ ) is a very familiar perennial herb that grows in various places, such as meadowland, roadsides, cultivated fields, canal water, and waste areas [26]. PM has been used as a remediation plant because of the large surface area of its fibrous roots and its phytoremediation ability [27-29]. Chekol et al. [30] mentioned that a large surface area of fibrous roots is related to intensive soil penetration. Terrestrial grasses are most often used in the remediation of organic compounds. In addition, Azmat et al. [31] observed that roots were important in accumulating compounds due to the direct exposure of toxic chemicals to these underground parts and their ability to transport the compounds to aboveground organs (shoots). Romeh [27] found that PM has the ability to phytoremediate soil polluted with azoxystrobin. In addition, PM was used in soil treated with Rumex dentatus leaf extract in order to enhance removing carbosulfan from soil [29]. Likewise, PM can take up chlorpyrifos residue from soil by its roots and leaves; therefore, PM can be utilized in reducing the chlorpyrifos amount in soil [32]. Based on the efficiency of this plant, we used it in phytoremediation to remove CYP from contaminated soil.

Combining plants with solubility enhancement surfactants may enhance the effectiveness of phytoremediation. This method depends on the use of a surfactant that increases the water solubility of hydrophobic 
organic compounds (HOCs) by reducing the surface tension and micellization [33, 34]. This study focused on four surfactants, liquid silicon dioxide $\left(\mathrm{SiO}_{2}\right)$, Tween 80 (Tw80), liquid humic acid (HA) and hydroxypropyl- $\beta$ cyclodextrin $(\mathrm{HP} \beta \mathrm{CD})$. These surfactants can accelerate the process of CYP residue uptake from the soil. This is due to their different mechanisms for increasing the bioavailability of CYP in the soil. Silicon ( $\mathrm{Si}$ ) is considered as one of the most essential elements for numerous plant species [35]. It is the second most abundant element in soil and the Earth's crust. It also plays an essential role in improving plant resistance to stress, which can be achieved by accumulating silicon in plant parts, including hulls, leaves, stems, and roots [36]. Moreover, the phytoremediation efficiency of Glycine max amended with $\mathrm{SiO}_{2}$ is better than that of Argal in the removal of fenamiphos residue from contaminated soil [37]. Few reports have focused on the role of $\mathrm{SiO}_{2}$ in improving pesticides uptake and the availability in contaminated soil. HP $\beta C D$ has been anticipated as a non-toxic and biodegradable alternative to surfactants and organic solvents to remove polycyclic aromatic hydrocarbons (PAHs) and other hydrophobic compounds from contaminated soil [38]. Notably, HP $\beta C D$ has been applied environmentally for enhancing the remediation efficiency of contaminated soils because of its ability to increase the apparent water solubility of low-polar organic compounds, which reduces their sorption and facilitates their transport through soil [39]. Therefore, this surfactant was considered as a good candidate for studying its ability to increase CYP bioavailability in soil to facilitate the phytoremediation process. HA has surfactant-like micelle microstructures which could enhance the organic compounds solubility of organic compounds and potentially increase the removal of hydrophobic organic compounds [40]. HA plays an important role in controlling the bioavailability of HOCs in aquatic environments [41]. Fava and Piccolo [42] showed that HA could enhance the bioavailability of Polychlorinated biphenyls (PCBs) in contaminated soils. The ability of HA to facilitate the removal of organic pollutants and increase their bioavailability was found in soil [43]. Smith et al. [44] found that the presence of HA could lead to a direct increase in phenanthrene removal from soil. Tw 80 is non-toxic to soil microorganisms and inert to the soil matrix and has the additional benefit of causing an enhanced dissolution rate for single compounds [45]. Ramamurthy and Memarian [46] indicated that Tw 80 can enhance the phytoremediation of soils polluted by mixed contaminants. In addition, the addition of the synthetic surfactant Tw 80 enhanced the solubility of endosulfan [47]. Consequently, we used these surfactants to increase the bioavailability of CYP and improve the uptake of CYP from polluted soil by PM.
Therefore, the aim of this study was to investigate the ability of PM to remediate CYP-polluted soil. The use of $\mathrm{SiO}_{2}$ and solubilization surfactants $(\mathrm{HP} \beta C D, \mathrm{HA}$ and $\mathrm{Tw}$ 80 ) for improving the bioavailability and uptake of CYPpolluted soil by PM was evaluated as a potential marvellous solution and curative method without high cost for the elimination of CYP pollution from the soil.

\section{Methods}

\section{Pesticide and surfactants}

The reference standard of CYP (99\% purity) was purchased from Sigma, China. The physical properties of CYP [48] are listed in Table 1. After planting, CYP was dissolved in acetone $(0.5 \mathrm{~mL})$ to obtain a concentration of $10 \mu \mathrm{g} \mathrm{g}^{-1}$ [49]. CYP at this concentration was added to the soil in the pots with irrigation water to avoid direct contact between CYP and the plant shoots.

$\mathrm{HA}, \mathrm{SiO}_{2}$, Tw80 and HP $\beta C D$ as surfactants were purchased from Sigma, China. Treatments included the following: $10 \mathrm{mg} \mathrm{L}^{-1} \mathrm{HA}, 750 \mathrm{mg} \mathrm{L}^{-1} \mathrm{SiO}_{2}, 9.2 \mathrm{mg} \mathrm{L}^{-1} \mathrm{Tw}$ 80 [corresponding to 0.5 critical micelle concentration $(\mathrm{CMC})]$ and $1.0 \% \mathrm{HP} \beta \mathrm{CD}$.

\section{Phytoremediation experiment setup and procedures}

Under greenhouse conditions, a pot experiment was conducted at the Institute of Pesticide Science, College of Plant Protection, Northwest A\&F University, Yangling, Shaanxi Province, China. The experiment was conducted under natural light conditions. The greenhouse temperature and relative humidity were $25-27^{\circ} \mathrm{C}$ and $66-69 \%$, respectively. For this experiment, the soil was collected from a plot in Yangling $\left(34^{\circ} 17^{\prime} 2^{\prime \prime} \mathrm{N}, 108^{\circ} 3^{\prime} 50^{\prime \prime} \mathrm{E}\right)$, Shaanxi Province, China. The sieved clay loamy soil was air dried (organic matter $18.2 \mathrm{~g} \mathrm{~kg}^{-1}$, $\mathrm{pH} 7.3$, electric conductivity $2.28 \mathrm{~S} \mathrm{~m}^{-1}$ ) then placed in plastic pots. Five hundred grams of soil was transferred to each plastic pot. PM seeds were purchased from a local market (Shangcheng, $31^{\circ} 47^{\prime} 43^{\prime \prime} \mathrm{N}, 115^{\circ} 24^{\prime} 4^{\prime \prime} \mathrm{E}$, Henan Province, China). PM seeds were sown during the winter season of 2017/2018; two PM seeds were planted per pot. After germination, the plants were thinned to one plant in each pot. The soil moisture content was adjusted to near the field capacity of the soils before the end of the growing season. The experimental pots were arranged according to a random

\section{Table 1 Physical and chemical properties of CYP}

\begin{tabular}{ll}
\hline Molecular weight & 416.3 \\
Water solubility & $4 \mathrm{ppb}$ at $20^{\circ} \mathrm{C}$ \\
Vapour pressure & $1.3 \times 10^{-9} \mathrm{mmHg}\left(20^{\circ} \mathrm{C}\right)$ \\
Henry's constant & $2.5 \times 10^{-7} \mathrm{~atm}-\mathrm{m}^{3} / \mathrm{mol}\left(20^{\circ} \mathrm{C}\right)$ \\
Octanol-water coefficient $\left(K_{\text {ow }}\right)$ & $3.98 \times 10^{6}$ \\
Soil adsorption coefficient $\left(K_{\text {oc }}\right)$ & $6.1 \times 10^{4} \mathrm{~mL} \mathrm{~g}^{-1}$ \\
\hline
\end{tabular}


design that consisted of eight treatments: (1) C: CYP-contaminated sterilized soil (CCSS) without P. major (PM), (2) $T_{1}$ : CYP-contaminated soil (CCS) without PM, (3) $T_{2}$ : CCS with PM only, (4) $T_{3}$ : CCSS with PM only, (5) $T_{4}$ : CCS with PM and amended with $\mathrm{SiO}_{2}$, (6) $T_{5}$ : CCS with PM and amended with HP $\beta C D$, (7) $T_{6}$ : CCS with PM and amended with HA, and (8) $T_{7}$ : CCS with PM amended with Tw80. 120 pots were used for all treatments, each treatment has 15 pots for five different times of sample collection, three replicates for each time. In each pot, one plant was grown for 14 days. After 1, 3, 7, 10, and 14 days from the times of exposure, the plants were collected from the treated soil for analysis. Plants were dissected and separated into roots and leaves. The plant roots were washed for three min in running tap water and dried. Ten grams of soil and four grams of roots and leaves were analysed for CYP residues.

According to Romeh and Hendawi [37], the removal percentage of CYP at the 1, 3, 7, 10 and 14 days of exposure was calculated as:

The percentage of removal $(\%)=\left(C_{0}-C_{1}\right) / C_{0} \times 100$

$C_{0}$ : initial CYP concentration in soil and $C_{1}$ : CYP concentration

\section{In vitro evaluation of surfactant efficacy in CYP adsorption} In vitro experiments were carried out to determine the equilibrium adsorption isotherms of CYP to determine the efficiency of surfactants in terms of CYP uptake from the soil. Four surfactants $\left(\mathrm{HP} \beta C D, \mathrm{SiO}_{2}, \mathrm{HA}\right.$ and Tw80) at the same concentrations as previously used in the greenhouse experiment were added to $100 \mathrm{~mL}$ glassstoppered conical flasks, and distilled water was used as a control. Three replicates were used in this experiment. CYP was then added to all of the conical flasks at $10 \mu \mathrm{g} \mathrm{mL}^{-1}$. The final volume of all solutions was $(20 \mathrm{~mL})$ in each flask. One gram of soil was added to all of these solutions and incubated with shaking for $3 \mathrm{~h}$; then, the resulting suspensions were kept at $27{ }^{\circ} \mathrm{C}$ for $24 \mathrm{~h}$. The suspensions were centrifuged at $15,000 \mathrm{rpm}$ for $10 \mathrm{~min}$, and the amount of CYP in supernatants were analysed by gas chromatography with an electron capture detector (GC-ECD) to determine the amount of CYP in the supernatants. According to Romeh and Hendawi [37], the amount of adsorbed CYP was calculated as the difference between the initial concentration of CYP and the concentration at equilibrium:

$$
x / m=\left(C_{0}-C_{\mathrm{e}}\right) V / W,
$$

where $x / m$ is the CYP concentration in the soil $\left(\mu \mathrm{g} \mathrm{g}^{-1}\right)$, $C_{0}$ is the initial concentration of CYP $\left(\mu \mathrm{g} \mathrm{mL}^{-1}\right), C_{\mathrm{e}}$ is the
CYP concentration at equilibrium ( $\left.\mu \mathrm{g} \mathrm{mL}^{-1}\right), V$ is the solution volume, and $W$ is the soil sample weight.

\section{Determination of CYP residue in the soil and PM}

The extraction of CYP residue was carried out by using the QuEChERS (quick, easy, cheap, effective, rugged and safe) method as described by Lehotay et al. [50]. In brief, $10 \mathrm{~g}$ of each soil type and $4 \mathrm{~g}$ of roots and leaves were placed into a $50-\mathrm{mL}$ centrifuge tube, and then $10 \mathrm{~mL}$ acetonitrile with $1 \%$ acetic acid was added. The samples were shaken vigorously for one min, and then six $\mathrm{g} \mathrm{MgSO}_{4}$, $1.5 \mathrm{~g} \mathrm{NaCl}$, and one g sodium citrate tribasic dehydrate $\left(\mathrm{Na}_{3}\right.$ citrate $)$ were added. Each tube was directly shaken after adding the salt. They were shaken vigorously for one min and then centrifuged for five min at $4000 \mathrm{U} \mathrm{min}^{-1}$. A $1 \mathrm{~mL}$ aliquot of supernatant was transferred to a dispersive clean-up tube containing $\mathrm{MgSO}_{4}$, graphitized carbon black (GCB), C18 and primary secondary amine (PSA). These tubes were shaken for $30 \mathrm{~s}$ and centrifuged for five $\min$ at $4000 \mathrm{U} \mathrm{min}^{-1}$.

The cleaned extract was analysed on a GC-2014C (Shimadzu) containing a capillary column using a Ni63 electron capture detector (ECD) for the detection of CYP. The separation of CYP was performed in a $30 \mathrm{~m} \times 0.25 \mathrm{~mm}$ internal diameter, $0.25 \mu \mathrm{m}$ thickness film submerged in a 5\% diphenyl, 95\% methylpolysiloxane HP-5MS column. Nitrogen gas was used as a carrier at 9.6 psi pressure

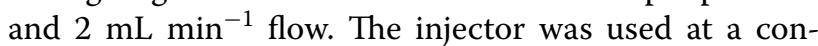
stant temperature of $280{ }^{\circ} \mathrm{C}$, whereas the detector temperature was $300{ }^{\circ} \mathrm{C}$. In addition, the initial temperature of the oven was $110^{\circ} \mathrm{C}$ (for $3 \mathrm{~min}$ isothermal) to $275^{\circ} \mathrm{C}$ (for $15 \mathrm{~min}$ isothermal). The injection volume was $1 \mu \mathrm{L}$. The GC method performance was estimated by evaluating some quality parameters, such as the recovery values, limits of quantification (LOQ) and limits of detection (LOD). LOQ and LOD were evaluated according to the following equations described by Thomsen et al. [51]:

$$
\mathrm{LOQ}=10 S_{0} / b \text {, and LOD }=3.3 S_{0} / b
$$

where $S_{0}$ is the calibration line standard deviation and $b$ is the slope.

The linearity was significant with an excellent correlation coefficient of $R=0.998$. The LOQ and LOD of CYP were $0.50 \mu \mathrm{g} \mathrm{g}^{-1}$ and $0.16 \mu \mathrm{g} \mathrm{g}^{-1}$, respectively. CYP recoveries at different levels of fortification, i.e., $0.05,0.1$ and $0.5 \mathrm{mg} \mathrm{kg}^{-1}$, were estimated from the soil, root and leaf samples. Under the selected conditions, we did not observe any interfering peaks on the sample chromatogram. The average ranges of recoveries for soil, root and leaves were $90.6-90.7 \%, 89.3-91.2 \%$ and $92.6-96.5 \%$, respectively. 
The degradation rate $(K)$ and half-life value $\left(t_{1 / 2}\right)$ were estimated according to the following equation reported by Belal and Gomaa [52],

$$
\begin{aligned}
& \text { The degradation } \operatorname{rate}(K)=2.303 \times \text { slope. } \\
& \text { Half-life value }\left(t_{1 / 2}\right)=0.693 \mathrm{~K}^{-1} .
\end{aligned}
$$

\section{Statistical analysis}

In this study, data were entered into the program Costat 6.311 software. Arithmetic mean and standard error were calculated. One-way ANOVA test was performed to compare between different treatments. If the $p$-value is less than 0.05 , we reject the null hypothesis that there is no difference between the means and conclude that a significant difference does exist. If the $p$-value is less than 0.05 , we cannot conclude that a significant difference exists. We performed the one-way ANOVA test by post hoc test using Duncan test to make multiple comparisons between averages of different treatments. The means followed by the same letter in each column are not significantly different from each other at the 5 percent probability level (Duncan's multiple range test).

\section{Results}

\section{Contribution of PM and some factors to increasing the bioavailability of CYP in the soil}

Under the different treatments, changes in the levels of CYP in the soil were measured over 1-14 days (Table 2) to determine the ability of PM to remove CYP from the soil and the contributions of the different surfactants to increasing the CYP bioavailability, microorganism abundance, improve PM performance, and amalgamation between PM and microorganisms, which result in CYP degradation in the soil. After 7 days, the percentages of CYP removal in the control group $(C)$ and the other experimental treatments were compared. The results in Table 2 show that the amalgamation between microorganisms and PM $\left(T_{3}-C\right)$ is the most effective treatment for CYP degradation in the soil, improving CYP degradation rates by $20.9 \%$ in comparison to the process of natural degradation, followed by the treatments with plants alone $\left(T_{2}-C\right)$ and microorganisms alone $\left(T_{1}-C\right)$, which improved degradation by 16.2 and $13.9 \%$, respectively. The contribution of $\mathrm{SiO}_{2}\left(T_{4}\right)$ to CYP uptake from the soil was greater than that of other solubilityenhancing surfactants across all experimental periods (Table 2). Whereas the contribution of $T_{4}$ to CYP uptake after 7 days was $14.9 \%$, the contributions of $T_{5}, T_{6}$, and $T_{7}$ to CYP uptake from the soil were $7.9,11.7$, and $5.4 \%$, respectively. During all experimental periods, the contributions of surfactants to the removal of CYP from the soil were found to be as follows: $\mathrm{SiO}_{2}>\mathrm{HP} \beta \mathrm{CD}>\mathrm{HA}>\mathrm{Tw} 80$.

\section{Dynamics of CYP in soil and plant tissues under different surfactant efficacies}

The CYP concentrations in the soil and plant tissues (roots and leaves) during the experiment are shown in Fig. 1. The data obtained during this study showed that all experimental groups containing plants removed a substantial amount of CYP. Amending the soil with PM plus the tested surfactants resulted in a decrease in CYP in the soil and then increased the CYP concentrations in the plant roots and leaves. $\mathrm{SiO}_{2}$ had a synergistic effect on the uptake and translocation of CYP. The phytoremediation efficiency of PM amended with $\mathrm{SiO}_{2}$ was higher than that of the other solubility-enhancing surfactants, with CYP being eliminated from the polluted soil during the experimental period. The most-effective to the least-effective supplements in the order of ability for use in combination with $\mathrm{PM}$ for CYP phytoremediation by roots were as follows: $\mathrm{SiO}_{2}>\mathrm{HP} \beta \mathrm{CD}>\mathrm{HA}>\mathrm{Tw} 80$. In the soil with $\mathrm{PM}$, the CYP concentration was in the range of $8.24-3.16 \mathrm{mg} \mathrm{kg}^{-1}$ over the 14 days of the experiment, while it was $9.47-3.84 \mathrm{mg} \mathrm{kg}^{-1}$ in the control soil. The CYP concentrations in the soil containing $\mathrm{PM}$ and amended with $\mathrm{SiO}_{2}, \mathrm{HP} \beta \mathrm{CD}, \mathrm{HA}$ and $\mathrm{Tw} 80$ reached 5.21, 5.53, 5.91 and $6.16 \mathrm{mg} \mathrm{kg}^{-1}$, respectively, after 7 days of exposure, while the concentration of CYP in the soil with PM alone was $8.24 \mathrm{mg} \mathrm{kg}^{-1}$. On the 14th day, the CYP concentrations in the soil with PM and the surfactants reached 1.58, 2.05, 2.22 and $2.73 \mathrm{mg} \mathrm{kg}^{-1}$, respectively, while CYP concentration in the control soil was $3.16 \mathrm{mg} \mathrm{kg}^{-1}$, and this difference was significant $(p>0.05)$ (Fig. 1a). $\mathrm{SiO}_{2}, \mathrm{HP} \beta C D$, HA and Tw80 had a synergistic effect on the uptake and translocation of CYP in the PM roots. Significant accumulation of CYP was observed in the roots (43.6, $40.1,38.8$, and $35.0 \mathrm{mg} \mathrm{kg}^{-1}$ ), and there was a significant difference in these values $(p>0.05)$ compared with the concentrations in the PM roots without surfactants $\left(32.7 \mathrm{mg} \mathrm{kg}^{-1}\right.$ ) at 7 days (Fig. 1b). On the 14th day, there were significant differences in the concentration of CYP in roots when the surfactants were applied (74.8, 71.2, 68.8 , and $63.8 \mathrm{mg} \mathrm{kg}^{-1}$, respectively) compared to that when $\mathrm{PM}$ was grown alone $\left(62.7 \mathrm{mg} \mathrm{kg}{ }^{-1}\right)(p>0.05)$. For the leaves, the ratios of uptake and translocation for CYP were significantly different $(p>0.05)$ in the presence of $\mathrm{SiO}_{2}, \mathrm{HP} \beta C D, \mathrm{HA}$ and Tw80 in combination with $\mathrm{PM}$ at 7 days, with values that were approximately $1.61,1.49,1.37$ and 1.25 times higher, respectively, than that with PM alone. However, on the 14th day, the ratios were $1.29,1.25,1.20$ and 1.15 times higher, respectively, than that for PM alone (Fig. 1c).

The total CYP accumulation in the entire plant under amendment with $\mathrm{SiO}_{2}, \mathrm{HA}, \mathrm{HP} \beta \mathrm{CD}$ and Tw 80 reached 
Table 2 Contributions of PM and surfactants to increasing the CYP bioavailability in soil

\begin{tabular}{|c|c|c|c|c|c|}
\hline Days & Treatment & CYP mg kg ${ }^{-1}$ & $\%$ Removal & $\%$ Contribution & \\
\hline \multirow[t]{8}{*}{1} & C: CCSS & $9.86 a$ & 1.40 & - & 0.0 \\
\hline & $T_{1}: \operatorname{CCS}$ & $9.47 \mathrm{~b}$ & 5.30 & Microorganisms $\left(T_{1}-C\right)$ & 3.90 \\
\hline & $T_{2}:$ CCSS $+P M$ & $9.07 c$ & 9.30 & $\mathrm{PM}\left(T_{2}-C\right)$ & 7.9 \\
\hline & $T_{3}: C C S+P M$ & $8.24 d$ & 17.60 & Combination $\left(T_{3}-C\right)$ & 16.20 \\
\hline & $T_{4}: \mathrm{CCS}+\mathrm{PM}+\mathrm{SiO}_{2}$ & $6.92 \mathrm{~g}$ & 30.80 & $\mathrm{SiO} 2\left(T_{4}-T_{3}\right)$ & 13.20 \\
\hline & $T_{5}: \mathrm{CCS}+\mathrm{PM}+\mathrm{HA}$ & $7.74 \mathrm{e}$ & 22.60 & $\mathrm{HA}\left(T_{5}-T_{3}\right)$ & 5.00 \\
\hline & $T_{6}: C C S+P M+H P \beta C D$ & $7.23 f$ & 27.70 & $\operatorname{HP\beta CD}\left(T_{6}-T_{3}\right)$ & 10.10 \\
\hline & $T_{7}: C C S+P M+T w 80$ & 7.98 de & 20.20 & $\operatorname{Tw} 80\left(T_{7}-T_{3}\right)$ & 2.60 \\
\hline \multirow[t]{8}{*}{3} & $C:$ CCSS & $9.34 \mathrm{a}$ & 6.60 & - & 0.0 \\
\hline & $T_{1}: \operatorname{CCS}$ & $8.46 \mathrm{~b}$ & 15.40 & Microorganisms $\left(T_{1}-C\right)$ & 8.80 \\
\hline & $T_{2}: C C S S+P M$ & $8.07 c$ & 19.30 & $\mathrm{PM}\left(T_{2}-\mathrm{C}\right)$ & 12.70 \\
\hline & $T_{3}: C C S+P M$ & $7.39 \mathrm{~d}$ & 26.10 & Combination $\left(T_{3}-C\right)$ & 19.50 \\
\hline & $T_{4}: \mathrm{CCS}+\mathrm{PM}+\mathrm{SiO}_{2}$ & $6.29 f$ & 37.10 & $\mathrm{SiO} 2\left(T_{4}-T_{3}\right)$ & 11.00 \\
\hline & $T_{5}: \mathrm{CCS}+\mathrm{PM}+\mathrm{HA}$ & $6.90 \mathrm{e}$ & 31.00 & $\mathrm{HA}\left(T_{5}-T_{3}\right)$ & 4.90 \\
\hline & $T_{6}: C C S+P M+H P \beta C D$ & $6.76 \mathrm{e}$ & 32.40 & $\operatorname{HP\beta CD}\left(T_{6}-T_{3}\right)$ & 6.30 \\
\hline & $T_{7}: C C S+P M+T w 80$ & $7.08 \mathrm{~d}$ & 29.20 & Tw $80\left(T_{7}-T_{3}\right)$ & 3.10 \\
\hline \multirow[t]{8}{*}{7} & $C:$ CCSS & $8.79 a$ & 12.10 & - & 0.0 \\
\hline & $T_{1}:$ CCS & $7.40 \mathrm{~b}$ & 26.00 & Microorganisms $\left(T_{1}-C\right)$ & 13.90 \\
\hline & $T_{2}: C C S S+P M$ & $7.17 b$ & 28.30 & $\mathrm{PM}\left(T_{2}-C\right)$ & 16.20 \\
\hline & $T_{3}: C C S+P M$ & $6.70 c$ & 33.00 & Combination $\left(T_{3}-C\right)$ & 20.90 \\
\hline & $T_{4}: \mathrm{CCS}+\mathrm{PM}+\mathrm{SiO}_{2}$ & $5.21 \mathrm{~g}$ & 47.90 & $\mathrm{SiO} 2\left(T_{4}-T_{3}\right)$ & 14.90 \\
\hline & $T_{5}: \mathrm{CCS}+\mathrm{PM}+\mathrm{HA}$ & $5.91 \mathrm{e}$ & 40.90 & $\mathrm{HA}\left(T_{5}-T_{3}\right)$ & 7.90 \\
\hline & $T_{6}: C C S+P M+H P \beta C D$ & $5.53 f$ & 44.70 & $\operatorname{HP\beta CD}\left(T_{6}-T_{3}\right)$ & 11.70 \\
\hline & $T_{7}: C C S+P M+T w 80$ & $6.16 d$ & 38.40 & Tw $80\left(T_{7}-T_{3}\right)$ & 5.40 \\
\hline \multirow[t]{8}{*}{10} & C: CCSS & $7.64 a$ & 23.60 & - & 0.0 \\
\hline & $T_{1}:$ CCS & $5.97 b$ & 40.30 & Microorganisms $\left(T_{1}-C\right)$ & 16.70 \\
\hline & $T_{2}: C C S S+P M$ & $5.74 b$ & 42.60 & $\mathrm{PM}\left(T_{2}-\mathrm{C}\right)$ & 19.00 \\
\hline & $T_{3}: C C S+P M$ & $5.30 \mathrm{c}$ & 47.00 & Combination $\left(T_{3}-C\right)$ & 23.40 \\
\hline & $T_{4}: \mathrm{CCS}+\mathrm{PM}+\mathrm{SiO}_{2}$ & $3.57 \mathrm{f}$ & 64.30 & $\mathrm{SiO} 2\left(T_{4}-T_{3}\right)$ & 17.30 \\
\hline & $T_{5}: \mathrm{CCS}+\mathrm{PM}+\mathrm{HA}$ & $4.10 \mathrm{e}$ & 59.00 & $\mathrm{HA}\left(T_{5}-T_{3}\right)$ & 12.00 \\
\hline & $T_{6}: C C S+P M+H P \beta C D$ & $4.01 \mathrm{e}$ & 59.90 & $\operatorname{HP\beta CD}\left(T_{6}-T_{3}\right)$ & 12.90 \\
\hline & $T_{7}: C C S+P M+T w 80$ & $4.74 d$ & 52.60 & $\operatorname{Tw} 80\left(T_{7}-T_{3}\right)$ & 5.60 \\
\hline \multirow[t]{8}{*}{14} & C: CCSS & $6.80 \mathrm{a}$ & 32.00 & - & 0.0 \\
\hline & $T_{1}:$ CCS & $3.84 \mathrm{~b}$ & 61.60 & Microorganisms $\left(T_{1}-C\right)$ & 29.60 \\
\hline & $T_{2}: C C S S+P M$ & $3.71 \mathrm{~b}$ & 62.90 & $\mathrm{PM}\left(T_{2}-C\right)$ & 30.90 \\
\hline & $T_{3}: C C S+P M$ & $3.16 \mathrm{c}$ & 68.40 & Combination $\left(T_{3}-C\right)$ & 36.40 \\
\hline & $T_{4}: \mathrm{CCS}+\mathrm{PM}+\mathrm{SiO}_{2}$ & $1.58 \mathrm{f}$ & 84.20 & $\mathrm{SiO} 2\left(T_{4}-T_{3}\right)$ & 15.80 \\
\hline & $T_{5}: \mathrm{CCS}+\mathrm{PM}+\mathrm{HA}$ & $2.22 \mathrm{e}$ & 77.80 & $\mathrm{HA}\left(T_{5}-T_{3}\right)$ & 9.40 \\
\hline & $T_{6}: C C S+P M+H P \beta C D$ & $2.05 \mathrm{e}$ & 79.50 & $\operatorname{HP} \beta C D\left(T_{6}-T_{3}\right)$ & 11.10 \\
\hline & $T_{7}: C C S+P M+T w 80$ & $2.73 d$ & 72.70 & Tw $80\left(T_{7}-T_{3}\right)$ & 4.30 \\
\hline
\end{tabular}

Different letters represent significant differences (Duncan's test significant difference test at $p<0.05$ ) among all treatments CCSS, CYP-contaminated sterilized soil; CCS, CYP-contaminated soil; PM, Plantago major; SiO $_{2}$, liquid silicon dioxide; HPßCD, 2-hydroxypropyl-beta-cyclodextrin; HA, liquid humic acid; Tw80, Tween 80

$66.72,61.57,58.52$ and $53.03 \mathrm{mg} \mathrm{kg}-1$ within 7 days, while the total accumulation was $47.04 \mathrm{mg} \mathrm{kg}^{-1}$ when PM was grown alone. At 14 days, the total CYP uptakes by $\mathrm{PM}$ after amendment with $\mathrm{SiO}_{2}, \mathrm{HA}, \mathrm{HP} \beta \mathrm{CD}$ and $\mathrm{Tw}$ 80 reached 125.71, 120.53, 116.37 and $109.19 \mathrm{mg} \mathrm{kg}^{-1}$, respectively, while the total uptake was $102.16 \mathrm{mg} \mathrm{kg}^{-1}$ when PM was grown alone. 


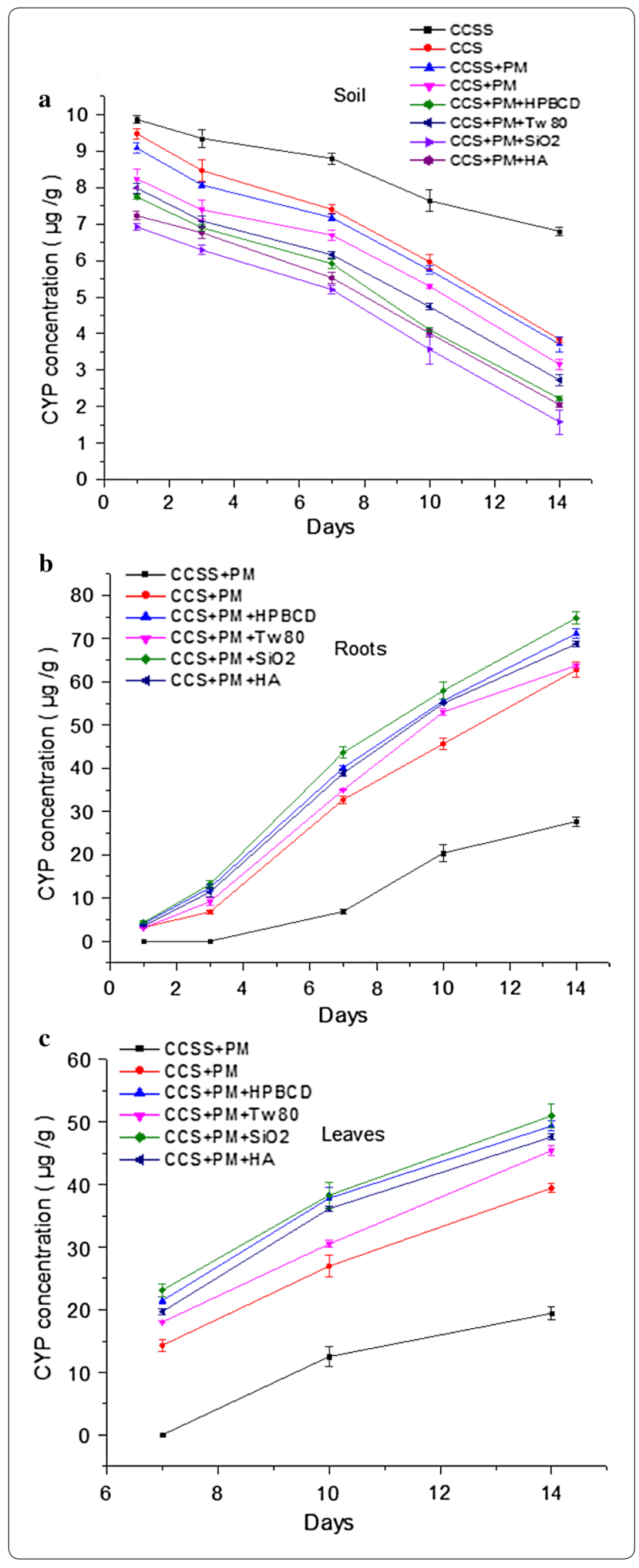

Enhancing the recovery of CYP from the soil

A batch equilibrium technique was used to evaluate the ability of the surfactants $\mathrm{HP} \beta C D, \mathrm{SiO}_{2}, \mathrm{HA}$ and Tw80 to adsorb the CYP from the soil by comparing
Fig. 1 Efficiency of solubility-enhancing agents $\left(\mathrm{SiO}_{2}, \mathrm{HP} \beta C D, \mathrm{HA}\right.$ and Tw 80) in phytoremediation of CYP contaminated soil using PM through 1-14 days of exposure. a CYP in soil, $\mathbf{b}$ CYP in roots, $\mathbf{c}$ CYP in leaves. Means and standard deviations of three replicates indicate significant differences $(p<0.05)$. CCSS, CYP-contaminated sterilized soil; CCS, CYP-contaminated soil; PM, (Plantago major); $\mathrm{SiO}_{2}$, liquid silicon dioxide; HPßCD, 2-hydroxypropyl-beta-cyclodextrin; HA, liquid humic acid; Tw80, Tween 80

the solubility-enhancing surfactants and distilled water. As shown in Fig. 2, $\mathrm{HP} \beta C D$ was found to be the most effective in decreasing the adsorption of CYP onto soils when compared with the other surfactants. The desorption of CYP in the soil showed the order $\mathrm{HP} \beta \mathrm{CD}>\mathrm{SiO}_{2}>\mathrm{HA}>\mathrm{Tw} 80$. The amount of $\mathrm{CYP}$ adsorbed by $\mathrm{HP} \beta C D$ from polluted soil was $47.5 \mu \mathrm{g} \mathrm{g}$ after $24 \mathrm{~h}$, while $\mathrm{SiO}_{2}, \mathrm{HA}$ and Tw80 adsorbed only 30.6, 22.5 and $13.6 \mu \mathrm{g} \mathrm{g}^{-1}$, respectively, with significant difference $(p>0.05)$ compared to the amount adsorbed by the soil $\left(72.1 \mu \mathrm{g} \mathrm{g}^{-1}\right)$.

\section{Reaction rate constants for CYP}

The removal of CYP from soil can be adequately described by a first-order reaction. According to the results shown in Fig. 3, the residual half-life values $\left(t_{1 / 2}\right)$ of CYP for all treatments were as follows: CCSS $>$ CCSS $+\mathrm{PM}>\mathrm{CCS}>\mathrm{CCS}+\mathrm{PM}>\mathrm{CCS}+\mathrm{PM}+\mathrm{Tw} 80>\mathrm{CCS}+\mathrm{P}$ $\mathrm{M}+\mathrm{HP} \beta \mathrm{CD}>\mathrm{CCS}+\mathrm{PM}+\mathrm{HA}>\mathrm{CCS}+\mathrm{PM}+\mathrm{SiO}_{2}$.

\section{Discussion}

Phytoremediation is an effective bioremediation technique which has been widely exploited to remediate various pesticide contaminants, including those in [53-55]. Many studies reported that microbial-plant interactions are highly effective in pesticides remediation [56-58]. Our results (Table 2) showed that the combination of PM $\left(T_{3}-C\right)$ and microorganisms were the best treatment for CYP degradation in soil. Phytoremediation is seemed to be improved by degradation processes resulting from the combined effects of microorganisms and plant in the rhizosphere [59]. This result confirms the work of Gurska et al. and Chen et al. [60, 61], who reported that microbial phytoremediation offers enormous potential for the remediation of soils that are contaminated by organic pollutants. In addition, pollutant-degrading bacteria might trigger adaptation in plants towards contaminants to detoxify polluted soils through direct mineralization of the organic contaminants [62]. Moreover, plant exudates have an effective role in increasing the activity and density of potential pollutant-degrading bacteria around plant roots [63]. In addition, plant root exudates can accelerate the bioremediation process of contaminants through stimulating growth and metabolism of the 


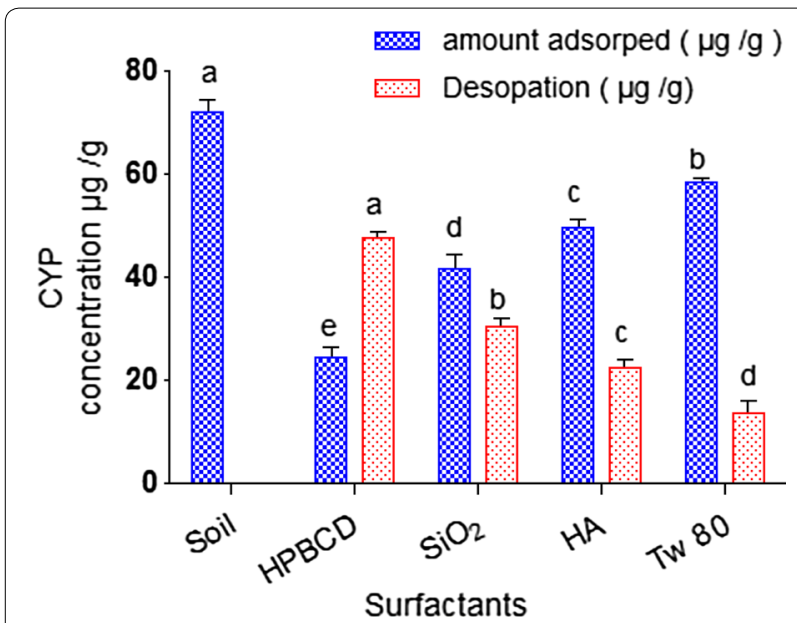

Fig. 2 Efficacy of surfactants in enhancing recovery of CYP from soil. Means and standard deviations of three replicates. Different letters on top of the bar indicate significant differences $(p<0.05) . \mathrm{SiO}_{2}$, liquid silicon dioxide; $\mathrm{HP} \beta C D$, 2-hydroxypropyl-beta-cyclodextrin; $\mathrm{HA}$, liquid humic acid; Tw80, Tween 80

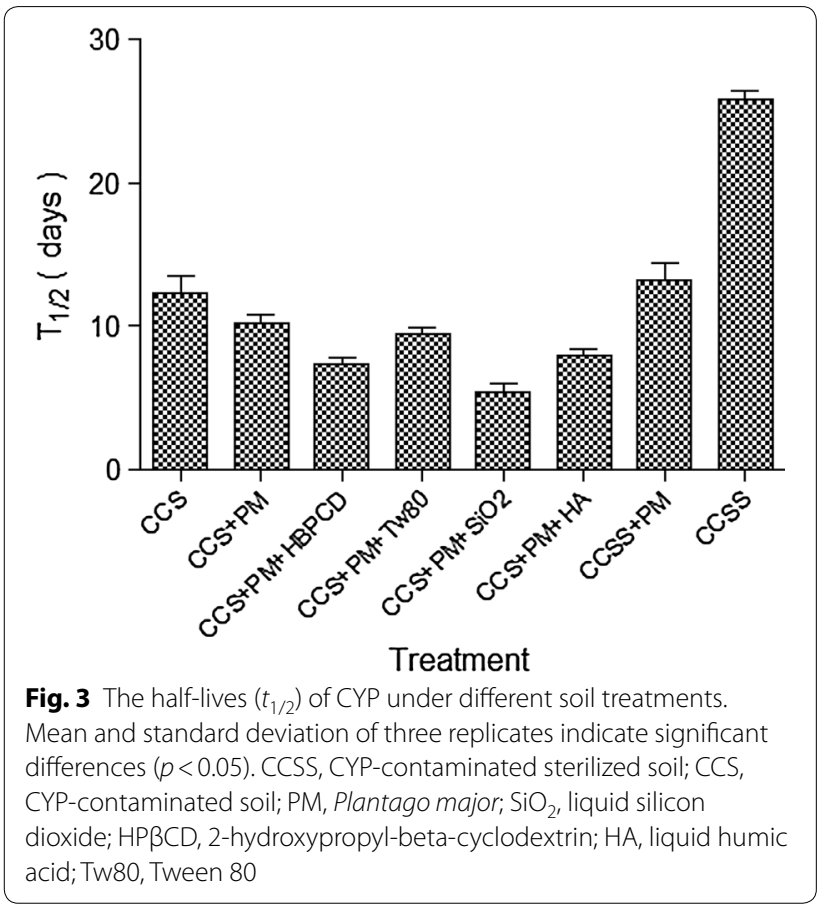

rhizospheric microorganisms [58]. For instance, Plantmicrobe associations between Withania somnifera and microorganisms can enhance the uptake of lindane [64].

Based on the results of this study, PM has the ability to take CYP up from the soil and plays a prominent role in increasing the removal of CYP from the soil. This ability is demonstrated because this plant not only has a large surface area of fibrous roots, which are often used in the remediation of organic compounds [30,31] but also the presence of bioactive compounds called polyphenolic compounds. These compounds have free radical scavenging ability via the presence of metal ion chelators and by naturalizing dangerous reactive oxidants [65]. Hence, it is a good plant for phytoremediation (Fig. 1, Table 2). These results are in agreement with Romeh [28], who demonstrated that PM is able to take up imidacloprid from the soil by roots and then leaves, so PM may be used for reducing pollution by imidacloprid in the soil. Likewise, PM was better than Glycine max and Helianthus annuus in decreasing azoxystrobin in contaminated soil [27]. Moreover, Mahmoud [66] reported that PM efficiently removed diazinon, pymetrozine and fipronil residue from soil and has the potential for use in pesticide phytoremediation. Consequently, this indicates that PM may play a major role in the removal of pesticides from contaminated soil. However, a plausible explanation for this finding is still required.

Amending soil with PM plus $\mathrm{SiO}_{2}$ resulted in a decrease in CYP in the soil at a rate of $30.8-84.2 \%$ from 1 to 14 days of exposure and increases in plant leaves and roots (Fig. 1, Table 2). This effect was demonstrated by the high adsorptive capacity of the form of silicic acid ions in the soil solution, resulting in complex formation with compounds in the soil and competition with other ions to link with the sites of adsorption [67]. In addition, the increased CYP uptake by PM together with $\mathrm{SiO}_{2}$ might have occurred because of the interaction among the plants, $\mathrm{SiO}_{2}$, and microbes, which could improve plant vigour and growth [25]. In addition, $\mathrm{Si}$ affects the binding of organic compounds to soil particles, making them more available for plant uptake [68]. Furthermore, $\mathrm{SiO}_{2}$ can cross membranes in response to a concentration differential. During its absorption and transport, $\mathrm{SiO}_{2}$ often interacts with the organic compounds (CYP) and other inorganic elements, enabling them to take part in various biochemical reactions within plant cells [69]. This process allows the plants to adsorb organic constituents from the soil, which is needed to facilitate phytoremediation. This result was obtained previously by Schaller et al. [70], who found that Si improved nutrient uptake capability, thereby improving soil fertility. In addition, Romeh and Hendawi [37] reported that the combination of Glycine max plus $\mathrm{SiO}_{2}$ was better than other solubility-enhancing surfactants (Argal) for reducing the level of fenamiphos in soil. However, the function of $\mathrm{SiO}_{2}$ in terms of enhancing the phytoremediation of soil polluted with pesticides is still required.

Numerous results have shown that $\mathrm{HP} \beta C D$ enhances soil desorption of different pesticides from soil [71-73]. 
$\mathrm{HP} \beta C D$ along with PM may serve as an enhancing agent for the phytoremediation of soil contaminated with CYP, whereas the rate of CYP removal from the soil was 27.7-79.5\% throughout the experimental period (Fig. 1, Table 2). This may be because HP $\beta C D$ is capable of complex formation with both solid and solution states with an assortment of molecules, which are placed in their hydrophobic interior cavity [74]. This result is a similar to that found by Mohamed et al. [75], who reported that $\mathrm{HP} \beta C D$, a type of solubility-enhancing surfactant, has various properties that are used for the remediation of soil contaminated with pesticides. Likewise, the application of HP $\beta C D$ to Point Pelee National Park (PPNP) soils improved microbial activity for the degradation of DDT and increased DDT phytoremediation by native grasses (Panicum virgatum and Schizachyrium scoparium) [76]. In addition, inclusion complexes of the hydrophobic herbicide bensulfuron-methyl (BSM) with $\mathrm{HP} \beta C D$ were prepared and characterized, and a phase solubility study showed that HP $\beta C D$ increased the solubility of BSM [77]. Furthermore, Villaverde et al. [78] found that $\mathrm{HP} \beta C D$ could increase desorption of the herbicide norflurazon from soils. Moreover, HP $\beta C D$ clearly shows an increase in the rate of mineralization of diuron in contaminated soils and a dissipation of half life time (DT50) values due to its increasing bioavailability [79]. In addition, the formation of inclusion complexes between norflurazon and $H P \beta C D$ provides the possibility of using $H P \beta C D$ to remove herbicides, such as norflurazon, or other toxic substances from contaminated soils [80]. Moreover, the addition of HP $\beta C D$ increased PCB bioavailability leading to enhanced PCB removal and plant uptake [81]. Furthermore, $\mathrm{HP} \beta C D$ can contribute to an improvement in the effectiveness of terbuthylazine in terms of its bioavailability in soil [82]. Fluorene and fluoranthene were removed from contaminated soils by $\mathrm{HP} \beta C D$ [83]. The results indicate the potential use of $\mathrm{HP} \beta C D$ for the remediation of pesticide-contaminated soils.

On the other hand, HA along with PM enhanced CYP removal with a rate of $22.6-77.8 \%$ throughout the experimental period (Fig. 1, Table 2). This enhancement might be due to HA being able to bind to compounds and change their speciation forms in soils [84]. Moreover, it can form metal complexes, isolate organic compounds, reduce and oxidize elements to and from toxic forms, photosensitize chemical reactions, and improve the uptake of toxic compounds by plants and microbial organisms [85]. These results are in agreement with those of Conte et al. [13], who found that the addition of HA increased the bioavailability of hydrophobic organic compounds (HOCs) in contaminated soils. Furthermore, the surfactant activity of HA was found to decrease the adsorption of organic contaminants from soils, thereby enabling desorption of PAH [40]. Moreover, Piccolo et al. [86] explained that HA can increase the bioavailability of atrazine in the soil. In addition, HA can reduce excessive soil contamination in aged industrially polluted soils [87]. Consequently, natural HA solutions may be a good option for surfactant-enhanced desorption in contaminated soils [40].

With regard to Tw80, several studies have shown that Tw80 plays a salient role in improving pesticide adsorption [88-90]. Based on the results of this study, Tw80 helped PM in the degradation of CYP from the soil at a rate of $20.2-72.7 \%$ from 1 to 14 days of exposure (Fig. 1, Table 2). This effect may be hypothesized to occur because CYP desorption by Tw80 in the soil may be dependent on the concentration of the surfactant, with an optimal concentration of approximately $0.5 \mathrm{CMC}$ [27]. This result is consistent with the previous report by Gao et al. [88], who reported that Tw80 can remove organic pollutants from contaminated soils via a mechanism involving the repartition of pollutants into micellar phases of the surfactant formed in water. However, this process would take place only when the surfactant solution reaches the surfaces of soil particles and pollutants may be desorbed into the micellar phases. Moreover, Tw 80 has been used to increase the bioavailability of the diazinon and dimethoate from the soil [90]. Furthermore, Romeh [27] found that Tw80 in the presence of PM could act as an enhancing surfactant for reducing the amount of azoxystrobin in polluted soil. In addition, the presence of Tw80 can enhance the transfer of mefenacet from the soil phase to the aqueous phase [89]. The surfactant Tw80 is a mobilizing agent for pollutants that facilitates their desorption from the soil matrix [91].

In equilibrium adsorption isotherms, $\mathrm{HP} \beta C D$ was better than the other surfactants (SiO2, HA, Tw80) in terms of the recovery of CYP from the soil. HP $\beta C D$ decreased the adsorption of CYP onto soils (Fig. 2). This effect may be because of the formation of inclusion complexes with CYP with a higher solubility in water than that of CYP and thus with a greater inclination to remain in solution as a complex than to be adsorbed onto the soil [78]. Through in vitro experiments, a batch equilibrium technique demonstrated that the use of HPßCD led to efficient CYP elimination from the soil. However, in the greenhouse experiment, $\mathrm{PM}$ took up a higher amount of CYP in the presence of $\mathrm{SiO}_{2}$. This result may be due to the interaction among microorganisms, $\mathrm{SiO}_{2}$, and $\mathrm{PM}$, which improves plant growth and activity and increases the uptake of compounds by plants [25]. In addition, Ma and Yamaji [92] found that these beneficial effects of $\mathrm{Si}$ were attributed to both $\mathrm{Si}$ deposited in various tissues and soluble Si. The high deposition of $\mathrm{Si}$ in tissue causes 
the formation of a physical barrier that enhances the strength and rigidity of the tissues.

On the basis of our results (Fig. 3), PM cannot degrade CYP but can only take CYP up from the soil, but soil microbes do play a salient role in CYP degradation. The longest half-life value $\left(t_{1 / 2}\right)$ of CYP was in the sterilized soil (24.8 days), and the shortest was in the soil amended with $\mathrm{SiO}_{2}$ (6.41 days). This may be due to the microbial degradation mechanism, which is summarized in three parts [93]. First, the target was adsorption; it passed onto the cell membrane surface and was a dynamic balance process that was also critical. Second, the target penetrated the cell membrane surface, and the efficiency and penetration rate were linked with the target isomer molecular structure. Finally, this target rapidly undergoes enzymatic reactions in the membrane. This result was obtained previously by Demoute [94], who noted that soil microbes play an effective role in the dissipation of CYP in the soil. Similarly, Akbar et al. [95] reported that the half-life $\left(T_{1 / 2}\right)$ values for CYP degradation by microbes in these soil treatments were 9-17 days.

\section{Conclusions}

Based upon the present study, it can be concluded that

1. Plantago major is able to remove cypermethrin from the soil by its roots and then its leaves, so Plantago major may be used a curative model for reducing the level of cypermethrin in the soil.

2 . Hydroxypropyl- $\beta$-cyclodextrin, liquid humic acid, liquid silicon dioxide and Tween 80 can act as surfactants for improving the phytoremediation of CYP from polluted soil, and liquid silica is the most effective surfactant in removing cypermethrin from the soil.

\section{Abbreviations \\ CYP: cypermethrin; PM: Plantago major; CCSS: CYP-contaminated sterilized soil; CCS: CYP-contaminated soil; $\mathrm{SiO}_{2}$ : liquid silicon dioxide; HPßCD: 2-hydroxypro- pyl-beta-cyclodextrin; HA: liquid humic acid; Tw80: Tween 80.}

\section{Acknowledgements}

The authors would like to express their thanks to Prof. Dr. Ali A. Aioub from the Faculty of Agriculture, Zagazig University, Egypt for his fruitful discussion. This study was supported by grants from the National Key Research and Development Program of China (2017 YFD0201402), from the Science and Technology Ministry of China and the National Natural Science Foundation of China (31672055), as well as the China Scholarship Council (CSC).

\section{Authors' contributions}

AAAA and $X Z$ designed the experiment in the green house and collected samples. AAAA and YL analysed cypermethrin residues in Gas chromatography. ZH supervised the study. AAAA and XQ contributed to the interpretation of the results and to the writing of the manuscript. All the authors read and approved the final manuscript.

\section{Funding}

This study was supported by grants from the National Key Research and Development Program of China (2017 YFD0201402), from the Science and Technology Ministry of China and the National Natural Science Foundation of China (31672055) as well as the China Scholarship Council (CSC).

\section{Availability of data and materials}

The datasets obtained and analysed in the current study are available from the corresponding author on reasonable request.

\section{Ethics approval and consent to participate}

Not applicable.

\section{Consent for publication}

Not applicable.

\section{Competing interests}

The authors declare that they have no competing interests.

\section{Author details}

${ }^{1}$ Institute of Pesticide Science, College of Plant Protection, Northwest A\&F University, Yangling 712100, Shaanxi, China. ${ }^{2}$ Provincial Key Laboratory for Botanical Pesticide R \& D of Shaanxi Province, Yangling 712100, Shaanxi, China. ${ }^{3}$ Plant Protection Department, Faculty of Agriculture, Zagazig University, Zagazig 44511, Egypt.

Received: 29 January 2019 Accepted: 27 April 2019

Published online: 07 May 2019

\section{References}

1. Liu Y-H, Chung Y-C, Xiong Y (2001) Purification and characterization of a dimethoate-degrading enzyme of Aspergillus niger ZHY256, isolated from sewage. Appl Environ Microbiol 67:3746-3749

2. FAOSTAT (2018) Statistics division. Rome: Food and Agriculture Organization of the United Nations. http://www.fao.org/faostat/en/\#data

3. California Department of Pesticide Regulation (2006) Pesticide use reporting (PRU). CDPR, Sacramento, CA. http://www.cdpr.ca.gov/docs/ pur.htm. Accessed 09 Jan 2006

4. Majumdar B, Guha G, Ray A, Bala B (2012) Toxic intracerebral demyelination in a case of suicidal Cypermethrin poisoning. Ann Trop Med Public Health 5:615

5. Fernandez-Alvarez M, Llompart M, Lamas JP, Lores M, Garcia-Jares C, Cela R, Dagnac T (2009) Development of a matrix solid-phase dispersion method for the simultaneous determination of pyrethroid and organochlorinated pesticides in cattle feed. J Chromatogr A 1216:2832-2842

6. Jin M, Li L, Xu C, Wen Y, Zhao M (2010) Estrogenic activities of two synthetic pyrethroids and their metabolites. J Environ Sci (China) 22:290-296

7. Morgan MK, Sheldon LS, Croghan CW, Jones PA, Chuang JC, Wilson NK (2007) An observational study of 127 preschool children at their homes and daycare centers in Ohio: environmental pathways to cis- and transpermethrin exposure. Environ Res 104:266-274

8. Al-Hamdani NMH, Narasinhachary YH (2011) Endocrine disruptive action of cypermethrin in male mice. Toxicol Environ Health Sci 3:69-79

9. Ostiz SB, Khan SU (1994) Nonextractable (bound) residues of cypermethrin in soils. Bull Environ Contam Toxicol 53:907-912

10. Fenoll J, Ruiz E, Flores P, Hellín P, Navarro S (2011) Reduction of the movement and persistence of pesticides in soil through common agronomic practices. Chemosphere 85:1375-1382

11. Carvalho FP (2017) Pesticides, environment, and food safety. Food Energy Secur 6:48-60

12. Meyer BN, Lam C, Moore S, Jones RL (2013) Laboratory degradation rates of 11 pyrethroids under aerobic and anaerobic conditions. J Agric Food Chem 61:4702-4708

13. Conte P, Agretto A, Spaccini R, Piccolo A (2005) Soil remediation: humic acids as natural surfactants in the washings of highly contaminated soils. Environ Pollut 135:515-522

14. Rock S, Pivetz B, Madalinski K, Adams N, Wilson T (2000) Introduction to phytoremediation. U.S. Environmental Protection Agency, Washington, D.C., EPA/600/R-99/107 (NTIS PB2000-106690) 
15. Carvalho PN, Basto MC, Almeida CM, Brix H (2014) A review of plantpharmaceutical interactions: from uptake and effects in crop plants to phytoremediation in constructed wetlands. Environ Sci Pollut Res Int 21(20):11729-11763

16. Moore MT, Tyler HL, Locke MA (2013) Aqueous pesticide mitigation efficiency of Typha latifolia (L.), Leersia oryzoides (L.) SW., and Sparganium americanum Nutt. Chemosphere 92(10):1307-1313

17. Lv T, Zhang Y, Zhang L, Carvalho PN, Arias CA, Brix H (2016) Removal of the pesticides imazalil and tebuconazole in saturated constructed wetland mesocosms. Water Res 91:126-136

18. Lambert M, Leven BA, Green RM (2014) Method of removing heavy metals in soils and waterUnited States. Briefs for Citizens, Kansas State University

19. Lv T, Zhang Y, Casas ME, Carvalho PN, Arias CA, Bester K, Brix H (2016) Phytoremediation of imazalil and tebuconazole by four emergent wetland plant species in hydroponic medium. Chemosphere 148:459-466

20. Ahmad R, Misra N (2014) Evaluation of phytoremediation potential of Catharanthus roseus with respect to chromium contamination. Am J Plant Sci 05:2378-2388

21. Hussain S, Siddique T, Arshad M, Saleem M (2009) Bioremediation and phytoremediation of pesticides: recent advances. Crit Rev Environ Sci Technol 39(10):843-907

22. Kerle EA, Jenkins JJ, Vogue PA. (2007) Understanding pesticide persistence and mobility for groundwater and surface water protection. Oregon State University Extension Services, EM8561-E

23. Turgut C (2005) Uptake and modeling of pesticides by roots and shoots of parrot feather (Myriophyllum aquaticum). Environ Sci Poll Res 12:342-346

24. Gao YZ, Zhu LZ (2003) Phytoremediation and its models for organic contaminated soils. J Environ Sci (China) 15:302-310

25. Bouldin JL, Farris JL, Moore MT, Smith S Jr, Cooper CM (2006) Hydroponic uptake of atrazine and lambda-cyhalothrin in Juncus effusus and Ludwigia peploides. Chemosphere 65:1049-1080

26. Sharifa AA, Neoh YL, Ismail M, Osman K, Abdul Halim M, Mohamed J, Mohamed Azman AB, Hing H (2008) Effects of methanol, ethanol and aqueous extract of plantago major on gram positive bacteria, gram negative bacteria and yeast. Ann Microsc 8:42-44

27. Romeh A (2015) Evaluation of the phytoremediation potential of three plant species for azoxystrobin-contaminated soil. Int J Environ Sci Technol 12:3509-3518

28. Romeh AA (2010) Phytoremediation of water and soil contaminated with imidacloprid pesticide by Plantago major L. Int J Phytoremediation 12:188-199

29. Romeh AA (2016) Efficiency of Rumex dentatus L. leaves extract for enhancing phytoremediation of Plantago major $L$. in soil contaminated by carbosulfan. Soil Sedim Contamin Int J 25:941-956

30. Chekol T, Vough LR, Chaney RL (2002) Plant-soil-contaminant specificity affects phytoremediation of organic contaminants. Int J Phytorem 4:17-26

31. Azmat R, Haider S, Riaz M (2009) An inverse relation between Pb2+ and $\mathrm{Ca} 2+$ ions accumulation in Phaseolus mungo and Lens culinaris under $\mathrm{Pb}$ stress. Pak J Bot 41:2289-2295

32. Romeh AA, Hendawi MY (2013) Chlorpyrifos insecticide uptake by plantain from polluted water and soil. Environ Chem Lett 11:163-170

33. Gomez J, Alcantara MT, Pazos M, Sanroman MA (2010) Remediation of polluted soil by a two-stage treatment system: desorption of phenanthrene in soil and electrochemical treatment to recover the extraction agent. J Hazard Mater 173:794-798

34. Saichek RE, Reddy KR (2004) Evaluation of surfactants/cosolvents for desorption/solubilization of Phenanthrene in clayey soils. Int J Environ Stud 61:587-604

35. Liang Y, Wong JWC, Wei L (2005) Silicon-mediated enhancement of cadmium tolerance in maize (Zea mays L.) grown in cadmium contaminated soil. Chemosphere 58:475-483

36. Emamverdian A, Ding $Y, X i e Y$, Sangari S (2018) Silicon mechanisms to ameliorate heavy metal stress in plants. Biomed Res Int 2018(3):1-10.

37. Romeh AA, Hendawi MY (2017) Biochemical interactions between Glycine max L. silicon dioxide ( $\mathrm{SiO} 2$ ) and plant growth-promoting bacteria (PGPR) for improving phytoremediation of soil contaminated with fenamiphos and its degradation products. Pestic Biochem Physiol 142:32-43
38. Gomes HI, Dias-Ferreira C, Ribeiro AB (2013) Overview of in situ and ex situ remediation technologies for PCB-contaminated soils and sediments and obstacles for full-scale application. Sci Total Environ 445-446:237-260

39. Villaverde J, Maqueda C, Morillo E (2006) Effect of the simultaneous addition of $\beta$-cyclodextrin and the herbicide norflurazon on its adsorption and movement in soils. J Agric Food Chem 54:4766-4772

40. Holman HY, Nieman K, Sorensen DL, Miller CD, Martin MC, Borch T, McKinney WR, Sims RC (2002) Catalysis of PAH biodegradation by humic acid shown in synchrotron infrared studies. Environ Sci Technol 36:1276-1280

41. Hahn D, Cozzolino A, Piccolo A, Armenante PM (2007) Reduction of 2,4-dichlorophenol toxicity to Pseudomonas putida after oxidative incubation with humic substances and a biomimetic catalyst. Ecotoxicol Environ Saf 66(3):335-342

42. Fava F, Piccolo A (2002) Effects of humic substances on the bioavailability and aerobic biodegradation of polychlorinated biphenyls in a model soil. Biotechnol Bioeng 77:204-211

43. Hassett JP (2006) Dissolved natural organic matter as a microreactor. Science 311(5768):1723

44. Smith KEC, Thullner M, Wick LY, Harms H (2009) Sorption to humic acids enhances polycyclic aromatic hydrocarbon biodegradation. Environ Sci Technol 43:7205-7211

45. Link A (2000) Effect of nonionic surfactants on dissolution of polycyclic aromatic hydrocarbons from coal tar. Pract Period Hazard Toxic Radioactive Waste Manag 4:78-81

46. Ramamurthy A, Memarian R (2012) Phytoremediation of mixed soil contaminants. Biotechnol Bioeng 72:103-111

47. Jayashree R, Vasudevan N (2007) Effect of tween 80 added to the soil on the degradation of endosulfan by Pseudomonas aeruginosa. Int J Environ Sci Technol 4:203-210

48. California Department of Pesticide Regulation. 2006. Pesticide use reporting 432 (PRU). CDPR, Sacramento, CA. http://www.cdpr.ca.gov/docs/pur. htm. Accessed 09 Jan 2006

49. Xie W, Zhou J (2008) Cypermethrin persistence and soil properties as affected by long-term fertilizer management. Acta Agric Scand Sect B Soil Plant Sci 58:314-321

50. Lehotay SJ, de Kok A, Hiemstra M, Van Bodegraven P (2005) Validation of a fast and easy method for the determination of residues from 229 pesticides in fruits and vegetables using gas and liquid chromatography and mass spectrometric detection. J AOAC Int 88:595-614

51. Thomsen V, Schatzlein D, Mercuro D (2003) Limits of detection in spectroscopy. Spectroscopy 18:112-114

52. Belal MH, Gomaa EA (1979) Determination of dimethoate residue in some vegetables and cotton plants. Bull Environ Contam Toxicol 22:726-730

53. Wang B, Wang Q, Liu W, Liu X, Hou J, Teng Y, Luo Y, Christie P (2017) Biosurfactant-producing microorganism Pseudomonas sp. SB assists the phytoremediation of DDT-contaminated soil by two grass species. Chemosphere 182:137-142

54. Zhang Y, LvT, Carvalho PN, Arias CA, Chen Z, Brix H (2016) Removal of the pharmaceuticals ibuprofen and iohexol by four wetland plant species in hydroponic culture: plant uptake and microbial degradation. Environ Sci Pollut Res Int 23(3):2890-2898

55. Lv T, Carvalho PN, Casas ME, Bollmann UE, Arias CA, Brix H, Bester K (2017) Enantioselective uptake, translocation and degradation of the chiral pesticides tebuconazole and imazalil by Phragmites australis. Environ Pollut 229:362-370

56. Carvalho PN, Arias CA, Brix H (2016) Removal of the pesticides imazalil and tebuconazole in saturated constructed wetland mesocosms. Water Res 91:126-136

57. Salam MMA, Kaipiainen E, Mohsin M, Villa A, Kuittinen S, Pulkkinen P, Pelkonen P, Mehtätalo L, Pappinen A (2016) Effects of contaminated soil on the growth performance of young Salix (Salix schwerinii E. L. Wolf) and the potential for phytoremediation of heavy metals. J Environ Manang 183(2):2123-2131

58. Macek T, Mackova M, Kas J (2000) Exploitation of plants for the removal of organics in environmental remediation. Biotechnol Adv 18(1):23-34

59. Cheng S, Xiao J, Xiao H, Zhang L, Wu Z (2007) Phytoremediation of Triazophos by Canna indica Linn. in a hydroponic system. Int J Phytoremediation 9(6):453-463 
60. Gurska J, Wang W, Gerhardt KE, Khalid AM, Isherwood DM, Huang XD, Glick BR, Greenberg BM (2009) Three year field test of a plant growth promoting rhizobacteria enhanced phytoremediation system at a land farm for treatment of hydrocarbon waste. Environ Sci Technol 43(12):4472-4479

61. Chen Y, Tang X, Cheema SA, Liu W, Shen C (2010) Beta-cyclodextrin enhanced phytoremediation of aged PCBs-contaminated soil from e-waste recycling area. J Environ Monit 12(7):1482-1489

62. Escalante-Espinosa E, Gallegos M, Favela-Torres E, Gutiérrez-Rojas M (2005) Improvement of the hydrocarbon phytoremediation rate by Cyperus laxus Lam. inoculated with a microbial consortium in a model system. Chemosphere 59:405-413

63. Siciliano SD, Germida JJ (1998) Mechanisms of phytoremediation: biochemical and ecological interactions between plants and bacteria. Environ Rev 6(1):65-79

64. Abhilash P, Srivastava S, Srivastava P, Singh B, Jafri A, Singh N (2011) Influence of rhizospheric microbial inoculation and tolerant plant species on the rhizoremediation of lindane. Environ Exp Bot 74:127e-130e

65. Zubair M (2010) Genetic and environmental effects on polyphenols in Plantago major report at Faculty of Landscape Planning, Horticulture and Agriculture Science, Swedish University of Agriculture Science

66. Mahmoud Rady Abd-el rahman Ramadan (2015) Phytoremediation of water and soil contaminated with some pesticides. Master degree. Zagazig University, Egypt

67. Tubana B, Heckman J (2015) Silicon in soils and plants. Springer, Cham, pp 7-51

68. Greger M, Landberg T, Vaculík M (2018) Silicon influences soil availability and accumulation of mineral nutrients in various plant species. Plants 7(2):41

69. Matichenkov VV, Calvert DV, Snyder GH (2000) Prospective of silicon fertilization for citrus in Florida. Proc Soil Crop Sci Soc 59:137-141

70. Schaller J, Brackhage C, Gessner MO, Bauker E, Gert Dudel E (2012) Silicon supply modifies C:N: P stoichiometry and growth of Phragmites australis. Plant Biol (Stuttg) 14(2):392-396

71. Villaverde J (2007) Time-dependent sorption of norflurazon in four different soils: use of beta-cyclodextrin solutions for remediation of pesticidecontaminated soils. J Hazard Mater 142(1-2):184-190

72. Ginés JM, Morillo González E, Moyano Méndez JR, Pérez-Martínez JI (2000) $1 \mathrm{H}$-nuclear magnetic resonance and phase solubility studies of the stoichiometries in 2,4-D: cyclodextrins inclusion complexes. J Incl Phenom Macrocycl Chem 37:171-178

73. Morillo González E, Posada Baquero R, Rubio Bellido M, Villaverde Capellán J (2013) Effect of hydroxypropyl-2-cyclodextrin on diuron desorption and mineralisation in soils. J Soils Sedim 13:1075-1083

74. Sanchez-Trujillo MA, Lacorte S, Villaverde J, Barata C, Morillo E (2014) Decontamination of polycyclic aromatic hydrocarbons and nonylphenol from sewage sludge using hydroxypropyl-beta-cyclodextrin and evaluation of the toxicity of leachates. Environ Sci Pollut Res Int 21:507-517

75. Mohamed MH, Wilson LD, Headley JV, Peru KM (2008) Novel materials for environmental remediation of tailing pond waters containing naphthenic acids. Process Saf Environ Prot 86:237-243

76. Dahmer CP, Rutter A, Zeeb BA (2018) The fate of DDT in soils treated with hydroxypropyl-beta-cyclodextrin (HPbetaCD). Int J Phytoremediat 20:523-529

77. Geng Q, Li T, Wang X, Chu W, Cai M, Xie J, Ni H (2019) The mechanism of bensulfuron-methyl complexation with $\beta$-cyclodextrin and 2-hydroxypropyl- $\beta$-cyclodextrin and effect on soil adsorption and bioactivity. Sci Rep 9(1):1882

78. Villaverde J, Maqueda C, Morillo E (2005) Improvement of the desorption of the herbicide norflurazon from soils via complexation with $\beta$-cyclodextrin. J Agric Food Chem 53(13):5366-5372
79. Rubio-Bellido M, Morillo E, Villaverde J (2016) Effect of addition of HPBCD on diuron adsorption-desorption, transport and mineralization in soils with different properties. Geoderma 265:196-203

80. Villaverde J, Morillo E, Pérez-Martínez Jl, Ginés JM, Maqueda C (2004) Preparation and characterization of inclusion complex of norflurazon and $\beta$-cyclodextrin to improve herbicide formulations. J Agric Food Chem 4(52):864-868

81. Costa C, Maia S, Silva P, Garrido J, Borges F, Garrido EM (2013) Photostabilization of phenoxyacetic acid herbicides MCPA and mecoprop by hydroxypropyl-2-cyclodextrin. Int J Photoenergy 2013:8

82. Garrido E, Rodrigues D, Milhazes N, Borges F, Garrido J (2017) Molecular encapsulation of herbicide terbuthylazine in native and modified $\beta$-cyclodextrin. J Chem 2017:9

83. Morillo E, Sanchez-Trujillo MA, Villaverde J, Madrid F, Undabeytia T (2014) Effect of contact time and the use of hydroxypropyl-beta-cyclodextrin in the removal of fluorene and fluoranthene from contaminated soils. Sci Total Environ 496:144-154

84. Burlakovs J, Klavinš M, Osinska L, Purmalis O (2013) The impact of humic substances as remediation agents to the speciation forms of metals in soil. APCBEE Procedia 5:192-196

85. Pandey AK, Pandey SD, Misra V, Devi S (2003) Role of humic acid entrapped calcium alginate beads in removal of heavy metals. J Hazard Mater 98:177-181

86. Piccolo A, Celano G, Conte P, Zena A, Spaccini R. Adsorption of atrazine on humic substances of different molecular structure and their hydrolysed products as modified by $\mathrm{pH}$. In: XI Symposium Pesticide Chemistry, Cremona; 1999, pp 425-431

87. Sannino F, Spaccini R, Savy D, Piccolo A (2013) Remediation of highly contaminated soils from an industrial site by employing a combined treatment with exogeneous humic substances and oxidative biomimetic catalysis. J Hazard Mater 261:55-62

88. Gao Y-Z, Ling W-T, Zhu L-Z, Zhao B-W, Zheng Q-S (2007) Surfactantenhanced phytoremediation of soils contaminated with hydrophobic organic contaminants: potential and assessment. Pedosphere 17:409-418

89. Guo H, Zhang J, Liu Z, Yang S, Sun C (2010) Effect of tween 80 and betacyclodextrin on the distribution of herbicide mefenacet in soil-water system. J Hazard Mater 177:1039-1045

90. Hernandez-Soriano MC, Mingorance MD, Pena A (2012) Desorption of two organophosphorous pesticides from soil with wastewater and surfactant solutions. J Environ Manage 95:223-227

91. Tomei MC, Daugulis AJ (2013) Ex situ bioremediation of contaminated soils: an overview of conventional and innovative technologies. Crit Rev Environ Sci Technol 43(20):2107-2139

92. Ma JF, Yamaji N (2006) Silicon uptake and accumulation in higher plants. Trends Plant Sci 11(8):392-397

93. Kumar S, Kaushik G, Dar M, Nimesh S, Javier LóPez-Chuken U, VillarrealChiu J (2018) Microbial degradation of organophosphate pesticides: a review. Pedosphere 28:190-208

94. Demoute JP (1989) A brief review of the environmental fate and metabolism of pyrethroids. Pestic Sci 27:375-385

95. Akbar S, Sultan S, Kertesz M (2015) Determination of cypermethrin degradation potential of soilbacteria along with plant growth-promoting characteristics. Curr Microbiol 70(1):75-84

\section{Publisher's Note}

Springer Nature remains neutral with regard to jurisdictional claims in published maps and institutional affiliations. 